\title{
Relationship between non-enzymatic glycosylation and changes in serum insulin-like growth factor-1 (IGF-1) and IGF-binding protein-3 levels in patients with type 2 diabetes mellitus
}

Received: 22 September 1997 / Accepted in revised form: 30 April 1998

\begin{abstract}
The possible occurrence of increased non-enzymatic glycosylation of serum insulin-like growth factor binding protein-3 (IGFBP-3) in vivo and the changes that would simultaneously occur in serum levels of IGFBP-3 and insulin-like growth factor-1 (IGF-I) were investigated. We measured levels of IGF-I and IGFBP-3 and the degree of glycation of total serum protein and IGFBP-3, in serum samples obtained from patients with poorly controlled noninsulin-dependent diabetes (type 2) and from age-matched non-diabetic controls. Type 2 diabetic patients had significantly higher glycated serum protein (GlyP) levels. GlyP significantly correlated with age in the control $(r=0.315$, $P<0.05)$ but not in the type 2 diabetes group. Control and diabetic subjects had comparable serum IGF-I levels and in both groups IGF-I levels tended to decrease with age $(r=-0.567, P<0.001$ and $r=-0.465, P<0.05$ for control and type 2 diabetic subjects, respectively). In the type 2 diabetes group, IGF-I levels showed a negative correlation with serum GlyP values $(r=-0.476, P<0.05)$. Type 2 diabetic and control patients had comparable serum IGFBP-3 levels, which were significantly higher in diabetic patients in the older age subgroups. A negative correlation was found between IGFBP-3 levels and age in the control $(r=-0.705, P<0.001)$ and in the type 2 diabetes groups $(r=-0.463, P<0.05)$. A significant negative correlation was found between IGFBP-3 levels and GlyP in control
\end{abstract}

A. M. Cortizo · N. V. Cédola · J. J. Gagliardino

CENEXA (Centro de Endocrinología Experimental y Aplicada), Facultad de Ciencias Médicas, Universidad Nacional de La Plata, (1900) La Plata, Argentina

P. D. K. Lee

Diagnostic System Laboratories, Webster, Texas, USA

H. Jasper

CEDIE (Centro de Investigaciones Endocrinológicas),

División de Endocrinología,

Hospital General de Niños "Ricardo Gutiérrez",

Buenos Aires, Argentina

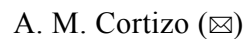

Bioquímica Patológica, Facultad de Ciencias Exactas,

Universidad Nacional de La Plata,

47 y 115, (1900) La Plata, Argentina
( $r=-0.449, P<0.002)$ but not in type 2 diabetic subjects. The mean glycated IGFBP-3 (GlyIGFBP-3) levels were higher in the oldest type 2 diabetic patients. In these patients, GlyIGFBP-3 was negatively associated with IGF-I levels $(r=-0.447, P<0.05)$. The IGF-I/IGFBP-3 molar ratio was significantly reduced in the 46-60-year-old type 2 diabetic group, whereas the IGF-I/IGFBP-3 ratio was positively and significantly correlated with GlyP levels only in the control group $(r=0.489, P<0.01)$. Our results show that: a) increased non-enzymatic glycosylation of IGFBP3 occurs in vivo; and $b$ ) this effect is accompanied by an increase in IGFBP-3 levels. These results suggest that the IGF-I/IGFBP-3 system is another target for the metabolic derangements of type 2 diabetes. Its alterations might play a role in diabetic complications.

Key words Non-enzymatic glycosylation · Insulin-like growth factor $\cdot$ Binding proteins $\cdot$ Chronic complications Diabetes mellitus

\section{Introduction}

Hyperglycaemia, a diagnostic feature of diabetes mellitus, leads to increased formation and accumulation of non-enzymatic protein glycation products $[1,2]$. Non-enzymatic glycation has been demonstrated to affect a number of proteins with relatively long half-lives (months to years), proteins with half-lives of days to weeks and in short-lived proteins [3-5].

Insulin-like growth factors I and II (IGF-I and IGF-II) are peptides which have been shown to have diverse mitogenic and metabolic effects [6-8]. IGF-I has been postulated to play an important role in the progression of diabetic vascular disease, retinopathy and nephropathy. In plasma, IGFs circulate bound to a family of high affinity binding proteins (IGFBPs) [9-11]. In postnatal life, the major IGFBP is IGFBP-3, which is almost completely saturated with IGFs [12]. IGF, IGFBP-3 and a unique acid-labile subunit (ALS) form a ternary complex which seques- 
ters more than $75 \%$ of the total circulating IGFs, each component depending directly or indirectly upon serum growth hormone levels [13]. The IGF contained in the ternary complex appears to be biologically inactive and only the free IGF-I serum fraction ( $<5 \%$ of total serum IGF-I levels) might be biologically active. Experimental evidence demonstrates that IGFBPs not only function as IGF carriers but also regulate their accessibility to cell-surface-specific receptors and their consequent bioactivity $[13,14]$.

We have previously reported that in untreated diabetic rats there is an increase in the amount of ${ }^{125}$ I-IGF-I bound to IGFBP-3 and that such an increase is related to the degree of serum protein glycation [15]. We have further demonstrated that: (a) IGFBP-3 can be non-enzymatically glycosylated in vitro; and (b) this process affects both IGFBP-3 binding properties and IGFBP-3 modulatory effect upon the mitogenic action of IGF-I [16]. Thus, if IGFBP-3 glycation occurs in vivo, the consecutive changes induced in its biological properties could contribute to the pathogenesis of growth defects and to the development of some chronic complications observed in patients with poorly controlled diabetes.

In order to test this hypothesis, we studied the levels of IGF-I, IGFBP-3 and its degree of non-enzymatic glycosylation as well as the total glycated protein. The study was carried out in serum samples obtained both from a group of control non-diabetic volunteers and from a group of type 2 diabetic patients with poor metabolic control.

\section{Subjects and methods}

Population sample

Twenty-three type 2 diabetic patients ( 9 men and 14 women; 35-70 years old; mean $57 \pm 2$ years) were studied. The degree of glycaemic control was assessed by measurement of fasting blood glucose (mean $14.4 \pm 0.72 \mathrm{mmol} / \mathrm{l}$ ) and glycated protein (GlyP) levels. According to the body mass index $\left(\mathrm{BMI}=\right.$ weight $/$ height $\left.^{2}\right), 48 \%$ of the type 2 diabetic patients were obese (BMI above 27 and 25 for men and women, respectively) [17]. Patients were treated with diet alone or diet plus an oral hypoglycaemic agent (glibenclamide), and none of them received insulin. The average duration of diabetes was $7.8 \pm 1.5$ years (range $1-24$ years). One patient had retinopathy and clinical signs of neuropathic complications, while none of them had clear signs of severe impairment of kidney function. Subjects in the non-diabetic control group included 43 adult volunteers (12 men and 31 women) with a mean age of $46 \pm 2$ years (range 20-70 years). In this group, $37 \%$ were obese as assessed by BMI. They had normal fasting blood glucose levels (mean $5.1 \pm 0.15 \mathrm{mmol} / \mathrm{l}$ ) and no evidence of diabetes, hypertension or any other hormonal or metabolic disease.

Involvement of human subjects in this project was approved by the institutional review board at CENEXA, and written informed consent was obtained from each subject prior to their involvement in this study.

\section{Assays}

Blood samples were obtained by peripheral venipuncture without anticoagulant, allowed to clot and then centrifuged; the serum obtained was then kept frozen at $-20^{\circ} \mathrm{C}$ until further use. Blood glucose was measured with the glucose GOD-PAP kit kindly provided by Boehringer Mannheim, Germany, Buenos Aires, Argentina.
Total glycosylated proteins. GlyP were measured after boronate-affinity chromatography, a method which relies on the affinity of the cis-diol group in stable glycated proteins for boronate anion [18]. In brief, $50 \mu \mathrm{l}$ serum was applied to a pre-equilibrated $1 \mathrm{ml}$ column containing agarose-immobilized boronic acid at room temperature. After $5 \mathrm{~min}$, the "unbound", non-glycated proteins were eluted with $10 \mathrm{ml}$ of $250 \mathrm{mmol} / 1 \mathrm{ammonium}$ acetate buffer, $\mathrm{pH}$ 8.0. The remaining "bound" glycated proteins were then eluted with $5 \mathrm{ml}$ of the $100 \mathrm{mmol} / 1$ Tris buffer containing $200 \mathrm{mmol} / 1 \mathrm{lsorbitol}, \mathrm{pH}$ 8.5. Protein concentrations in each fraction were assayed using the method of Bradford [19]. Aliquots of these samples were then concentrated (10-20 fold concentration) using an Amicon-10 filter (Amicon, Beverly, Mass., USA) and stored at $-20^{\circ} \mathrm{C}$ for later use in the IGFBP-3 assay.

IGFBP-3 radioimmunoassay (RIA). IGFBP-3 levels were measured using a commercial RIA kit (Diagnostic Systems Laboratories Inc. Webster, Texas, USA). Serum samples were diluted 1:100 and assayed according to the manufacturer's instructions which have shown that the analytical sensitivity of this IGFBP-3 assay is $0.9 \mathrm{ng} / \mathrm{ml}$ and that the inter- and intra-assay coefficients of variation (6 replicates each) range from 5.3 to $6.7 \%$ and 4.2 to $8.2 \%$, respectively. Parallel curves were obtained using serial dilutions of either IGFBP-3 standard or human serum samples.

IGF-I assay. Total IGF-I levels were determined in the samples by RIA after serum extraction by the acid-ethanol method [20]. For assay purposes, hrIGF-I (Bachem Inc., Torrance, Calif., USA) was used as standard and tracer. The hormone was iodinated with ${ }^{125}$ I by means of the chloramine-T method [21] at a specific activity of 400-450 $\mu \mathrm{Ci} / \mu \mathrm{g}$ and purified on a Sephadex G-50 column [22]. The rabbit polyclonal antibody (UBK487), employed at 1:10 000 dilution, was a generous gift from Dr. L. E. Underwood (Division of Pediatric Endocrinology, University of North Carolina at Chapel Hill, USA). The intra- and inter-assay coefficients of variation were 10.9 and $13.0 \%$, respectively. Under our working conditions, serial dilutions of rhIGF-I standard and extracted serum gave parallel displacement curves.

The IGF-I/IGFBP-3 molar ratio was calculated considering an estimated molecular weight of 7600 for IGF-I and 40000 for IGFBP-3. This molar ratio has been extensively used in the past as an indirect index of "free" IGF-I [23].

\section{Statistical analysis}

Results are expressed as mean \pm SEM. For data analysis, samples were divided into 4 age groups: $\leq 29,30-45,46-60$ and over 60 years. Differences between groups were assessed by the Student's $t$-test. Due to the number of the groups a comparison between age-matched controls and type 2 diabetic patients was feasible only in the 46-60 year and over 60 year groups. The correlation among different parameters was analysed using the Pearson's correlation coefficient as well as the linear and multiple regression method. RIA data were analysed using the RIA Data Reduction Program for the IBM-PC [24].

\section{Results}

Table 1 shows the data for non-diabetic control and diabetic subjects grouped according to age. All diabetic patients had statistically significantly higher serum GlyP levels than control subjects, data which coincided with the high fasting glucose levels found in the former. The levels of total glycated protein showed a positive and significant correlation with the age of the subjects in the control $(r=0.315, P<0.05, n=45)$ but not in the type 2 diabetes group. We did not statistically compare control and type 2 
Table 1 Parameters measured in control and diabetic patients

\begin{tabular}{lccllll}
\hline Group $(n)$ & $\begin{array}{c}\text { Age } \\
\text { (years) }\end{array}$ & $\begin{array}{l}\text { Gly Protein } \\
(\%)\end{array}$ & $\begin{array}{l}\text { IGFBP-3 } \\
(\mathrm{mg} / \mathrm{l})\end{array}$ & $\begin{array}{l}\text { Gly IGFBP-3 } \\
(\%)\end{array}$ & $\begin{array}{l}\text { IGF-I } \\
(\mu \mathrm{g} / \mathrm{l})\end{array}$ & $\begin{array}{l}\text { IGF-I/IGFBP-3 } \\
(\mathrm{mol} / \mathrm{mol})\end{array}$ \\
\hline Control (8) & $<29$ & $3.6 \pm 0.60$ & $4.0 \pm 0.36$ & $3.6 \pm 0.6$ & $176 \pm 23$ & $0.22 \pm 0.03$ \\
Control (14) & $30-45$ & $3.5 \pm 0.21$ & $4.4 \pm 0.16$ & $3.5 \pm 0.5$ & $154 \pm 13$ & $0.21 \pm 0.02$ \\
Type 2 diabetes (3) & & $10.4 \pm 2.30$ & $3.2 \pm 0.50$ & $4.5 \pm 3.2$ & $133 \pm 64$ & $0.19 \pm 0.08$ \\
Control (13) & $46-60$ & $3.3 \pm 0.35$ & $2.4 \pm 0.20$ & $2.9 \pm 0.3$ & $108 \pm 7$ & $0.25 \pm 0.02$ \\
Type 2 diabetes (11) & & $10.0 \pm 1.80$ & $4.4 \pm 0.49$ & $3.9 \pm 0.6$ & $120 \pm 11$ & $0.16 \pm 0.02$ \\
& & $P<0.01$ & $P<0.001$ & N.S. & N.S. & $P<0.01$ \\
Control (8) & $>60$ & $4.8 \pm 0.78$ & $1.9 \pm 0.15$ & $2.7 \pm 0.3$ & $97 \pm 16$ & $0.28 \pm 0.06$ \\
Type 2 diabetes (9) & & $12.4 \pm 0.90$ & $3.0 \pm 0.28$ & $3.8 \pm 0.4$ & $108 \pm 17$ & $0.23 \pm 0.04$ \\
& & $P<0.001$ & $P<0.01$ & $P<0.05$ & N.S. & N.S. \\
\hline
\end{tabular}

Data are means \pm SEM

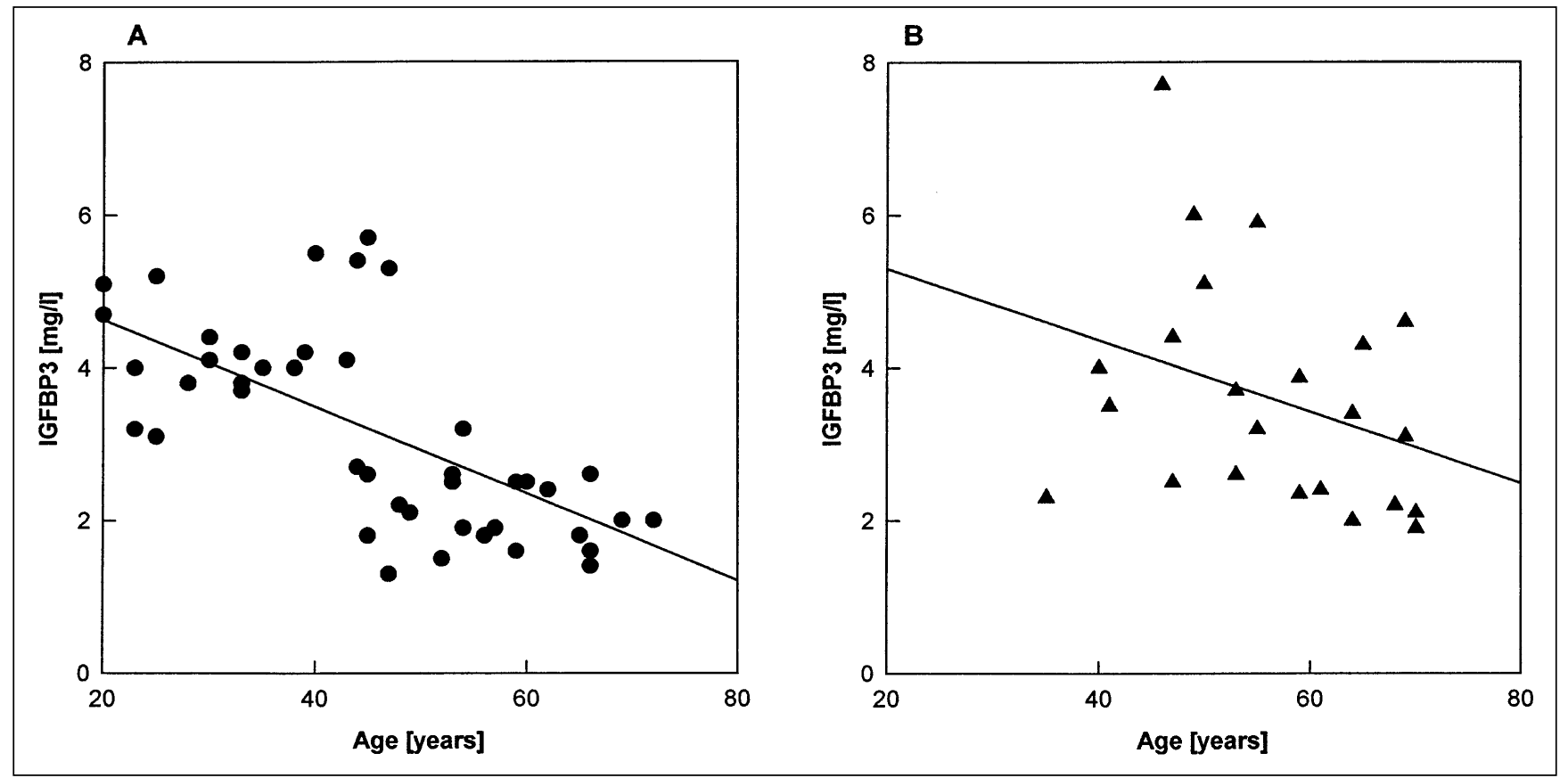

Fig. 1 Correlation of IGFBP-3 levels with the age of control (A) $(r=-0.705, P<0.001)$ and type 2 diabetic $(\mathbf{B})(r=-0.463, P<0.05)$ patients. Regression curve equations: $y=5.795-0.0578 x$ and $y=$ $6.237-0.047 x$, for control and type 2 diabetic patients, respectively

diabetic patients in the $30-45$ year group due to the inadequate number of diabetic subjects.

Control and diabetic subjects had comparable serum IGF-I levels both when the sample was considered as a whole $(138.4 \pm 11.8$ vs $118.9 \pm 10.6 \mu \mathrm{g} / 1$, respectively) and after the subjects had been grouped by age (Table 1). IGF-I levels exhibited a trend of decreasing values with the increase of age on both groups $(r=-0.576, P<0.001$ and $r=-0.465, P<0.05$ for control and type 2 diabetic subjects, respectively).

In the type 2 diabetes group, the IGF-I levels showed a negative correlation with serum GlyP values $(r=-0.476$, $P<0.05)$. There were no significant correlations between IGF-I levels and duration of diabetes or BMI.

Comparable serum IGFBP-3 levels were measured in type 2 diabetic and control subjects (mean, $3.61 \pm 0.31$ vs
$3.16 \pm 0.20 \mathrm{mg} / 1$, respectively). The mean values measured in diabetic patients in the 46-60 and over 60 years subgroups were significantly higher than those in control subjects (Table 1).

As shown in Fig. $1 \mathrm{~A}$, a negative correlation was found between IGFBP-3 levels and the age of the subjects both in the control $(r=-0.705, P<0.001$; Fig. $1 \mathrm{~A})$ and in the type 2 diabetes groups $(r=-0.463, P<0.05$; Fig. 1B). Furthermore, the strong trend of decreasing IGFBP-3 levels with increasing GlyP present in the control group $(r=$ $-0.449, P<0.002 ; y=4.747-0.382 x)$ was not found in type 2 diabetic subjects $(r=-0.299, P=0.165 ; y=4.713-$ $0.101 x$ ).

In control subjects, a strong linear correlation was observed between IGFBP-3 and IGF-I levels $(r=0.511$, $P<0.001$; Fig 2A). This association was absent in the type 2 diabetic group $(r=0.267, P=0.217$; Fig. 2B).

In order to investigate the extent of IGFBP-3 glycation in vivo, the total IGFBP-3 in serum was separated by affinity boronate chromatography as stated in Subjects and methods. In control subjects, the "bound" glycated 

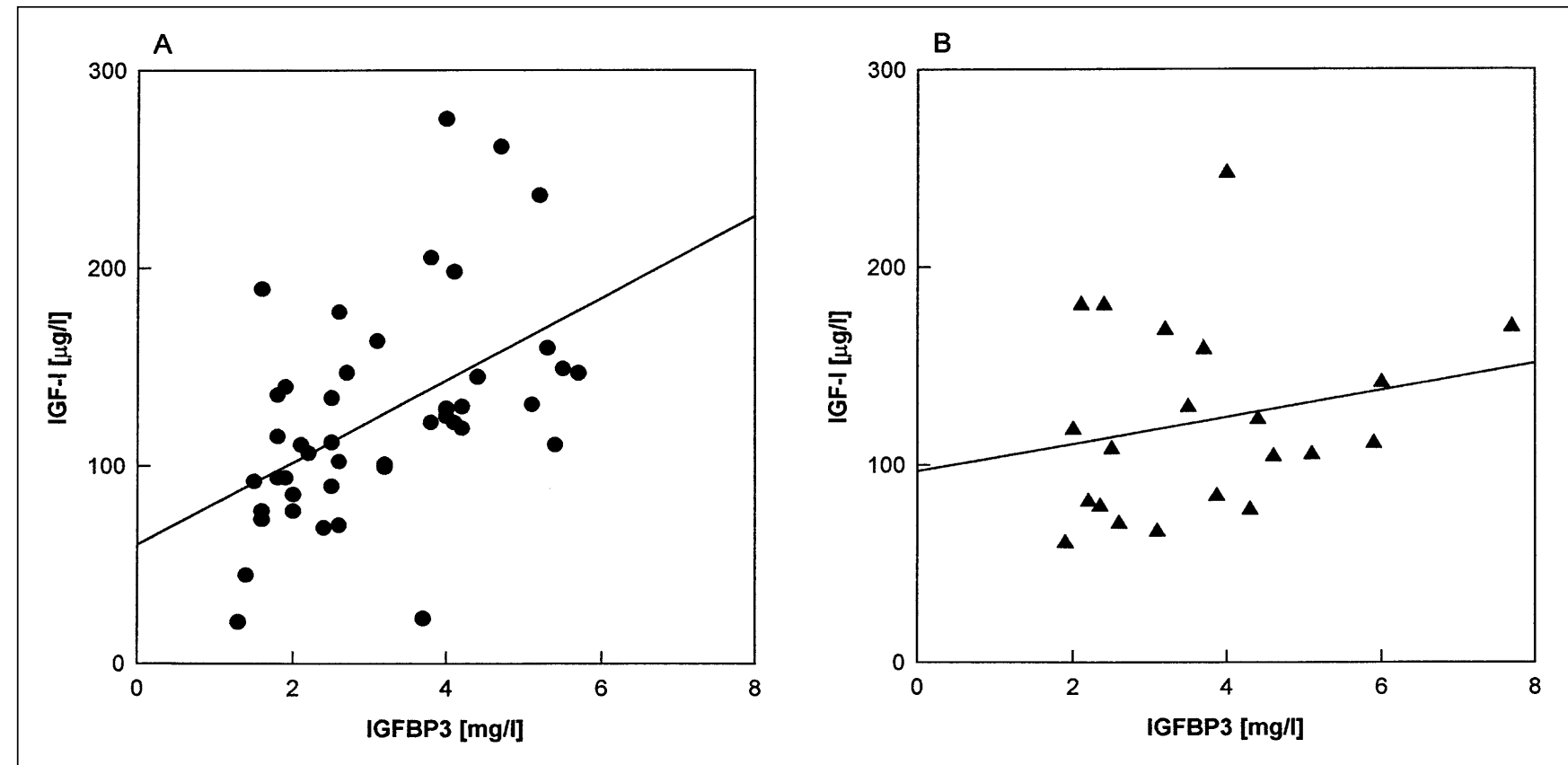

Fig. 2 Correlation between IGF-I and IGFBP-3 levels in control (A) $(r=0.511, P<0.001)$ and type 2 diabetic $(\mathbf{B})(r=0.267, P=0.217)$ patients. Regression curve equations: $y=42.61+30.33 x$ and $y=$ $86.46+8.998 x$, for control and type 2 diabetic patients, respectively

IGFBP-3 fraction had a mean value of $3.1 \pm 0.21 \%$, being slightly though not significantly higher in type 2 diabetic patients $(4.18 \pm 0.65 \%)$. When the subjects were grouped by age, the mean GlyIGFBP-3 levels showed a trend to increase in type 2 diabetic patients, but the difference only attained statistical significance in the oldest subgroup (Table 1).

No correlation was found between GlyIGFBP-3 levels and age of the subjects $(r=-0.204, P=0.179$ and $r=-0.324$, $P=0.131$ for control and type 2 diabetes, respectively) or GlyP levels $(r=0.002, P=0.861$ and $r=0.176, P=0.421$ for control and type 2 subjects) in either group. In diabetic patients, the glycated IGFBP-3 fraction was negatively associated with IGF-I levels $(r=-0.447, P<0.05)$.

The IGF-I/IGFBP-3 ratio had comparable mean values in the control and in the type 2 diabetic groups $(0.24 \pm 0.01$ and $0.19 \pm 0.02$, respectively). When the subjects were grouped by age, the mean ratio was significantly reduced only in the 46-60 year type 2 diabetic subgroup (Table 1 and Fig. 3). The IGF-I/IGFBP-3 ratio was not related to age, but it was significantly related to GlyP levels only in the control group $(r=0.489, P<0.01)$.

\section{Discussion}

As expected, there was an increase in the degree of nonenzymatic glycosylation of serum protein in patients with poorly controlled type 2 diabetes. The IGFBP- 3 glycated fraction was also larger in these patients, but the difference

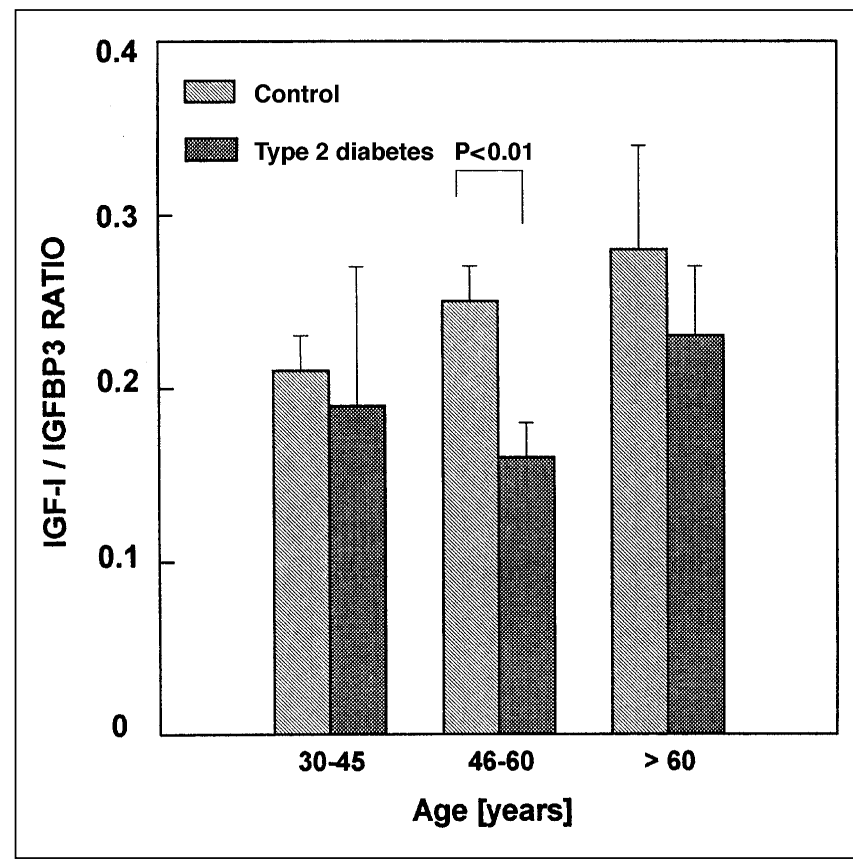

Fig. 3 IGF-I/IGFBP-3 ratio in non-diabetic control and type 2 diabetic patients grouped by age. Data represent mean \pm SEM. The number of cases is shown in Table 1

only attained statistical significance in patients older than 60 years (Table 1). Thus, the increased protein glycation which occurs in patients with sustained hyperglycaemia also affects IGFBP-3, a process that is apparently more marked in older patients.

In addition, the IGFBP-3 levels were higher while the IGF-I/IGFBP-3 ratio was lower in the 46 to 60 -year-old type 2 diabetic than in the corresponding control subjects. Serum IGF-I and IGFBP-3 levels are strongly influenced 
by age [25-27]; thus, this variable should be taken into consideration in a statistical evaluation of the changes observed in these two parameters in both experimental groups.

The levels of IGF-I and IGFBP-3 showed a trend to decrease as a function of age in the control group. This agedependence of serum IGF-I levels has been previously reported in the literature [28-30]. Conflicting results, however, have been published regarding IGF-I levels in diabetic patients, namely, decreased [25,31,32], increased in type 1 but normal in type 2 [33] or even unchanged [34, 35]. Our data would suggest that in type 2 diabetic and in control subjects IGF-I levels undergo a similar age-dependent variation with no significant changes in their absolute values when the comparison is done between groups paired by age.

IGFBP-3 levels decreased as a function of age in type 2 diabetic patients and in the control group (Fig. 1) as has been previously reported in this latter group [23, 27, 36],

Bang et al. [37] have recently reported that basal immunoreactive IGFBP-3 levels in type 2 diabetic patients do not differ from those measured in healthy obese and non-obese subjects. The discrepancy between our data and theirs may only be apparent and ascribed to differences in the respective protocols. In the previous study [37], only six type 2 diabetic patients with heterogeneous degrees of metabolic control were included; different types of treatment were used, and results were not compared against proper age-matched controls. In fact, the diabetic patients were older than the controls. Conversely, we employed a larger population of diabetic patients, all of them uncompensated and without insulin treatment (Table 1), and comparisons were done with control patients grouped by age.

We do not find a clear explanation for the IGFBP-3 increase. Excess growth hormone secretion does not seem to be implicated, since a concomitant IGF-I increase would be expected. The patients had neither clinically evident renal failure nor were under glucocorticoid treatments (both being known to increase IGFBP-3 levels) [26]. Other possible causes are changes in the IGFBP-3 half-life or in its proteolitic activities.

In our control group, the levels of GlyP increased as a function of the age of the subjects, but this relation was absent in the diabetic group. This fact would suggest that the increased non-enzymatic glycosylation of serum proteins observed in poorly controlled diabetic patients does not depend on their chronological age.

A negative correlation was found between GlyP and IGFBP-3 levels in the control group; thus, in diabetic patients we might expect to find lower IGFBP-3 levels than in control patients. Since we found the opposite, we could assume that in type 2 diabetic patients the normal relationship between GlyP and IGFBP-3 levels was broken and replaced by another which superseded such control.

The IGF-I/IGFBP-3 ratio gives an estimation of the free IGF-I fraction and its bioactivity [23]. This ratio was lower - though only significantly different in the 46-60 age group in diabetic patients. We also found a statistically significant increase in the glycated IGFBP-3 as a percentage of total serum IGFBP-3 in type 2 diabetic patients over 60 years old. However, in contrast with other serum proteins [4] this was a small increment probably due to the short half-life of the IGFBP-3 [9].

In brief, our results show that: (a) the non-enzymatic glycation of IGFBP-3 occurs in vivo, as shown in poorly controlled diabetic patients; (b) this effect is accompanied by an increase in the serum levels of IGFBP-3; (c) a decrease in the IGF-I/IGFBP-3 ratio in the 46-60 year group, possibly indicating a reduction in the free IGF-I fraction. Altogether, these results suggest that the IGF-I/IGFBP-3 system is another target for the metabolic derangements of type 2 diabetes. Its alterations might play a role in diabetic complications.

Acknowledgements This work was partially supported with funds provided by the CONICET of Argentina. We thank Miss Nyria Fenoglio for secretarial support. A. M. C. is a member of the Carrera del Investigador CICPBA, H. J. and J. J. G. are members of the Carrera del Investigador CONICET and N. V. C. is a member of the Carrera del Personal de Apoyo Profesional CONICET, Argentina.

\section{References}

1. Brownlee M, Vlassara H, Cerami A (1984) Nonenzymatic glycosylation and the pathogenesis of diabetes complications. Ann Intern Med 101:527-537

2. Brownlee M, Cerami A, Vlassara H (1988) Advanced products of non-enzymatic glycosylation and the pathogenesis of diabetes vascular disease. Diabetes Metab Rev 4:437-457

3. Bernstein RE (1987) Nonenzymatic glycosylated proteins. Adv Clin Chem 26: 1-78

4. Bucala R, Vlassara H, Cerami A (1992) Advanced glycosylation and products. In: Hardin JJ, Crabbe MJC (eds) Posttranslational modification of proteins. CRC Press, Boca Raton, pp 53-99

5. Witztum JL, Mahoney EM, Banks JM, Fisher M, Elam R, Steinberg D (1982) Nonenzymatic glycosylation of low density lipoprotein alters its biological activity. Diabetes 31:382-391

6. Baxter RC (1986) The somatomedins: insulin-like growth factors. Adv Clin Chem 25:49-115

7. Rechler MM, Nissley SP (1990) Insulin-like growth factors. In: Sporn MB, Roberts AB (eds) Peptide growth factors and their receptors. Springer-Verlag, Berlin Heidelberg New York, pp 263-346

8. Jones JI, Clemmons DR (1995) Insulin-like growth factors and their binding proteins: biological actions. Endocr Rev 16:3-34

9. Clemmons DR (1992) IGF binding proteins: regulation of cellular actions. Growth Regul 2:80-87

10. Bach LA, Rechler MM (1995) Insulin-like growth factor binding proteins. Diabetes Rev 3:38-61

11. Gelato MC, Alexander D, Marsh K (1992) Differential tissue regulation of insulin-like growth factor binding proteins in experimental diabetes mellitus in the rat. Diabetes 41:1511-1519

12. Martin JL, Baxter RC (1992) Insulin-like growth factor binding protein-3: Biochemistry and physiology. Growth Regul 2:88-99

13. Baxter RC, Martin JL (1989) Binding proteins for the insulinlike growth factors: structure, regulation and function. Prog Growth Factor Res 1:49-68

14. Herrington SC (1991) Insulin-like growth factors: biochemistry and physiology. Clin Endocrinol Metab 5:531-551

15. Cortizo AM, Gagliardino JJ (1991) Protein glycation: its role in the changes induced by diabetes in the properties of the serum insulin-like growth factor binding proteins. J Endocrinol $131: 33-38$

16. Cortizo AM, Gagliardino JJ (1994) Changes induced by non-enzymatic glycosylation of insulin-like growth factor (IGF)-binding protein-3 on its binding properties and on its modulatory effect of IGF-I mitogenic action. J Endocrinol 144:119-126 
17. Diabetes Data Group (1979) Classification and diagnosis of diabetes mellitus and other categories of glucose intolerance. Diabetes 28: 1039-1057

18. Yatscoft RW, Tevaarwk GJM, Mac Donald JC (1984) Quantification of non enzymatic glycated albumin and total serum protein by affinity chromatography. Clin Chem 30:446-449

19. Bradford MM (1976) A rapid and sensitive method for the quantitation of microgram quantities of protein utilizing the principle of protein-dye binding. Anal Biochem 72:248-254

20. Daughday WL, Mariz IK, Blethen SL (1980) Inhibition of access of bound somatomedin to membrane receptor in immunoblotting sites; a comparison of radioreceptor and radioimmunoassay of somatomedin in native and ethanol-extracted serum. J Clin Endocrinol Metab 51:781-788

21. D'Ercole AJ, Underwood LE, Van Wyk JJ, Decedue CJ, Foushee DB (1976) Specificity, topography and ontogeny of the somatomedin $\mathrm{C}$ receptor in mammalian tissue. In: Pecile $\mathrm{A}$, Muller R (eds) Growth hormone and related peptides. Excerta Medica, Amsterdam, pp 190-205

22. Furlanetto RW, Underwood LE, Van Wyk JJ, D’Ercole AJ (1977) Estimation of somatomedin-C levels in normal and patients with pituitary disease by immunoassay. J Clin Invest 60:648-657

23. Juul A, Main K, Blum W et al. (1994) The ratio between serum levels of insulin-like growth factor (IGF)-I and the IGF binding proteins (IGFBP-1, 2 and 3) decreases with age on healthy adults and is increased in acromegalic patients. Clin Endocrinol 41:85-93

24. Rodbard D (1984) Lessons form the computerization of radioimmunoassays: an introduction to the basic principles of modeling. In: Rodbard D, Fort G (eds) Computers in endocrinology. Raven Press, New York, pp 75-99

25. Tan K, Baxter RC (1986) Serum insulin-like growth factor I levels in adult diabetic patients: the effect of age. J Clin Endocrinol Metab 63:651-655

26. Poehlman ET, Copeland KC (1990) Influence of physical activity on insulin-like growth factor-I in healthy younger and older men. J Clin Endocrinol Metab 71:1468-1473
27. Blum W, Ranke M (1991) Plasma IGFBP-3 levels as clinical indicators. In: Spencer EM (ed) Modern concepts of insulin-like growth factors. Elsevier, New York, pp 381-393

28. Bennett AE, Wahner HW, Riggs BL Hintz RL (1984) Insulinlike growth factor I and II: aging and bone density in women. J Clin Endocrinol Metab 59:701-704

29. Clemmons DR, Van Wyk JJ (1984) Factors controlling blood concentration of somatomedin. Clin Endocrinol Metab 13:113143

30. Rosenfeld RG, Wilson DM, Lee PDK Hintz RL (1986) Insulinlike growth factors I and II in evaluation of growth retardation. J Pediatric 109:428-433

31. Dills DG, Moss SE, Klein BEK (1991) Association of elevated IGF-I levels with increased retinopathy in late-onset diabetes. Diabetes 40: 1725-1730

32. Bouillon R, Bex M, Van Herck et al. (1995) Influence of age, sex, and insulin on osteoblast function: osteoblast dysfunction in diabetes mellitus. J Clin Endocrinol Metab 80:1194-1202

33. Merimee TJ, Zapf J, Froesch ER (1983) Insulin-like growth factors: studies in diabetes with and without retinopathy. N Engl J Med 309:527-530

34. Horner JM, Kemp SF, Hintz RL (1981) Growth hormone and somatomedin in insulin-dependent diabetes mellitus. J Clin Endocrinol Metab 53:1148-1153

35. Lamberton RP, Goodman AD, Kassoff A, Rubin CL, Treble DH, Saba TM, Merimée TL, Dodds WJ (1984) Von Willebrand factor (VIIIR:Ag), fibronectin, and insulin-like growth factor I and II in diabetes retinopathy and nephropathy. Diabetes 33:125-129

36. Baxter RC, Martin JL (1986) Radioimmunoassay of growth hormone-dependent insulin like growth factor binding protein in human plasma. J Clin Invest 78: 1504-1512

37. Bang P, Brismar K, Rosenfeld RG Hall K (1994) Fasting affects serum insulin-like growth factors (IGF) and IGF-binding proteins differently in patients with non insulin dependent diabetes mellitus versus healthy non obese and obese subjects. J Clin Endocr Metab 78:960-967 